\title{
Studies on the Effect of Plant Growth Regulators on Growth, Flowering and Xanthophyll Content of African Marigold (Tagetes erecta L.)
}

\author{
V. Thirumal Murugan*, K. Manivannan and S. Nanthakumar \\ Department of Horticulture, Faculty of Agriculture, Annamalai University, \\ Annamalai Nagar, TamilNadu, India \\ *Corresponding author
}

Keywords

African marigold, Growth hormones, NAA, $\mathrm{GA}_{3}$, Maleic Hydrazide, Alar

Article Info

Accepted:

25 October 2020

Available Online:

10 November 2020

\begin{abstract}
A B S T R A C T
Production of marigold can be improved to a large extent by the judicious cultural operations i.e. application of optimum fertilizer at required time, crop management practices and use of plant growth regulators. Hence, an experiment was carried out in the Research Farm of Adhiparasakthi Horticultural College, Kalavai, during 2018-19 to find out the effect of plant growth regulators (NAA, $\mathrm{GA}_{3}$ ) and growth retardants (Maleic hydrazide, Alar) on growth and yield of African marigold var. Pusa Narangi Gainda. The experiment was conducted in randomized block design with three replications. Biometric observations on plant height, number of branches, number of leaves, leaf area, days to first flowering, flower head diameter, single flower weight, number of flowers per plant, flower yield per plant and Xanthophyll content were recorded at 90 days after planting and statistically analyzed. Results of the experiment revealed that among the growth hormones tested, considering the flower yield per plant, the treatment with NAA @ 150 ppm recorded for the maximum number of flowers with increased flower weight resulted in maximizing the flower yield $\left(447.2 \mathrm{~g} \mathrm{plant}^{-1}\right)$ with xanthophyll content $\left(18.80 \mathrm{~kg}^{-1}\right.$ of petal meal $(\mathrm{g}))$.
\end{abstract}

\section{Introduction}

African marigold (Tagetes erecta L.), a major source of Lutein, is also grown as a traditional loose flower and a garden flower in addition to being grown for its medicinal values. This pigment has acquired greater significance because of its excellent colour value. Nowadays the use of growth regulators play an important role by increasing, reducing or modifying the physiological process within plant and which ultimately affect the growth, flowering and yield. Gibberellic acid and NAA plays a vital role in improving the vegetative growth characters of the plants as it enhances the elongation and cell division by promoting the DNA synthesis in the cell. It reduced the juvenile phase due to increase in photosynthesis and respiration with enhanced $\mathrm{CO}_{2}$ fixation in the plant. Therefore, present experiment was undertaken in order to study the effect of NAA, $\mathrm{GA}_{3}$ on growth and yield of African marigold. Plant growth retardants are growth regulating chemical substances 
that find extensive use in the field of floriculture for modifying plant growth and development. Maleic Hydrazide and Alar are the two well-known growth retardants used for producing quality plants that are now being tried in African marigold. In this present investigation, various levels of recommended dosage of fertilizers in addition with Vermicompost, Humicacid and micro nutrients were tried to enhance growth and flower yield of African marigold.

\section{Materials and Methods}

An attempt was made to find out the effect of plant growth regulators (NAA @ 50, 100 and 150 ppm: GA $3 @ 100,200$ and 300 ppm) and growth retardants (Maleic Hydrazide @ 250, 500 and 750 ppm and Alar @ 600, 800 and $1000 \mathrm{ppm})$ on growth and yield of African Marigold in the Experimental farm of the Adhiparasakthi Horticultural College, G. B. Nagar, Kalavai, during the year 2017-19. The regulators were applied as foliar spray at 20 days after transplanting. The effect of thirteen treatments was studied under Randomized Block Design with three replications. Each treatment was applied to a plot of $3 \times 3 \mathrm{~m}$ size with plants spaced at $45 \mathrm{x} 35 \mathrm{~cm}$. Observations on plant height, number of branches, number of leaves, leaf area, days to first flowering, number of flowers, flower head diameter, flower yield and xanthophyll content were recorded and statistically analyzed.

\section{Results and Discussion}

Analysis of variance showed significant influence of growth hormones on plant height, number of branches, stem girth, number of leaves, leaf area, days to first flower emergence, flower stalk length, flower head diameter, single flower weight, number of flowers per plant, flower yield per plant and Xanthophyll content. Growth regulators find their extensive use in flower crops for modifying their developmental processes including growth and flowering. NAA and $\mathrm{GA}_{3}$ are most used regulators; Maleic hydrazide and Alar are the growth retardants used for producing quality plants that are now being tried in African marigold. Hence, in this present study, two growth regulators (NAA and $\mathrm{GA}_{3}$ ) two growth retardants (Maleic hydrazide and Alar) were applied as foliar spray with the objective to assess the response of marigold for growth and flower yield.

All the plant growth hormones exhibited significant differences on growth and flower yield of African marigold. The treatment $\mathrm{T}_{6}$ (Naphthalene acetic acid @ 150 ppm) recorded the maximum plant height (35.34 $\mathrm{cm}, 86.23 \mathrm{~cm}$ and $112.47 \mathrm{~cm}$ ), maximum leaf area $\left(132.5 \mathrm{~cm}^{2}\right)$, days to first flowering (53.93 days), flower diameter $(6.96 \mathrm{~cm})$, flower weight $(7.29 \mathrm{~g})$, number of flowers(61.34). The increased effect in the growth parameters in those plants treated with NAA spray. Metabolites partition and channelization helped in apical dominance which ultimately improved the length of the longest primary branch as application of NAA might be increased the plant vigour which promotes rooting and improves efficiency of nutrient uptake. Overall increase in biomass may be attributed to the fact that NAA increases $\mathrm{CO}_{2}$ fixation, chlorophyll content of leaves and photosynthate assimilation. These results are in close conformity with those of Kumar et al., (2012) and Gowda and Jayanthi (1991).

The flower characters were significantly influenced by NAA application. There was significant increase in the number and weight of flower heads per plant due to NAA spray. The increase in fresh weight of floral heads with the spray of NAA over control might be due to mobilization or movement of nutrients in to flowers. 
Table.1 Effect of plant growth regulators on various growth, flowering and quality characters of African marigold var. Pusa Narangi Gainda

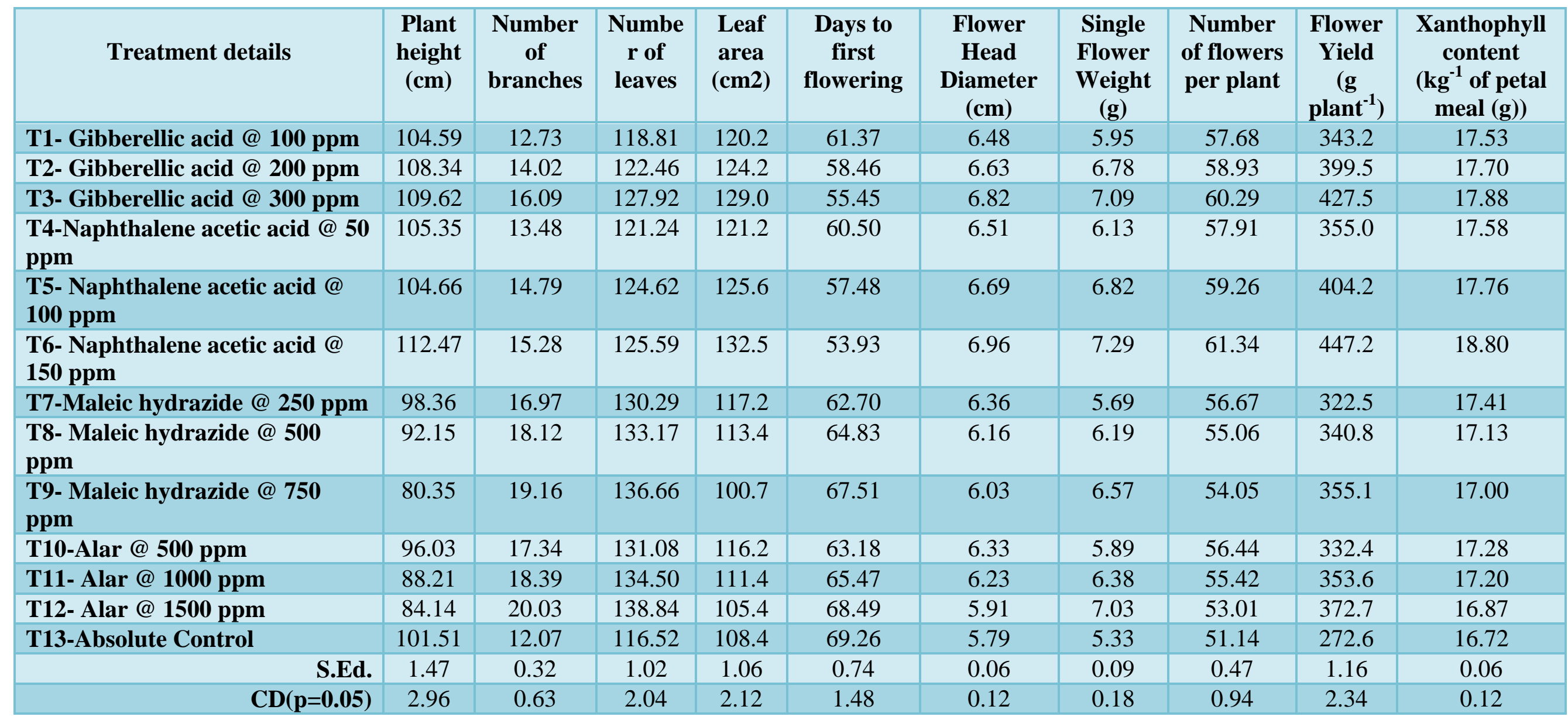


This also explains that NAA helps in sink source ratio maintenance. Similar effect of NAA has been reported by Ramdevputra (2009). The size of the floral head was also improved significantly over control by the application of NAA. Such changes in the size of floral head and their number per plant were due to NAA application which may be attributed to mobilization of hormones and metabolites.

This is closely followed by the treatment $T_{3}$ (Gibberellic acid @ 300 ppm) which recorded a plant height $33.72 \mathrm{~cm}, 83.88 \mathrm{~cm}$ and 109.62 $\mathrm{cm}$ in 30, 60 and 90 DAT respectively, leaf area $\left(129.0 \mathrm{~cm}^{2}\right)$, days to first flowering (55.45 days), stalk length $(9.36 \mathrm{~cm})$, flower diameter $(6.82 \mathrm{~cm})$, flower head weight $(7.09$ $\mathrm{g})$, number of flowers (60.290 and a flower yield of $427.5 \mathrm{~g} \mathrm{plant}^{-1}$. The favorable effect of $\mathrm{GA}_{3}$ might be attributed due to the fact that $\mathrm{GA}_{3}$ promotes cell division and cell elongation resulting in longer pedicel length. The results are in conformity with the findings of Tyagi and Kumar (2006), Kumar et al., (2011) and Arti Arhar et al., (2019) in African marigold.

On the other hand, the growth retardants also significantly influenced the growth and flowering of marigold in the present experiment. The plants treated with both $\mathrm{MH}$ reduced plant height $(20.75 \mathrm{~cm}, 55.80 \mathrm{~cm}$ and 80.35) when compared with control at 30,60 and 90 days after transplanting respectively. The treatment $\mathrm{T}_{12}$ (Alar @ 1500 ppm) produced maximum number of branches (10.71, 16.82 and 20.03 branches), maximum stem girth $(4.31,4.53 \mathrm{~cm}$ and $5.42 \mathrm{~cm})$, highest number of leaves $(52.46,97.62$ and 138.84) at 30, 60 and 90 days after transplanting respectively.

Since, $\mathrm{MH}$ and Alar belongs to anti-auxins and also possibly anti-gibberellins have reduced the plant height thereby increased number of branches, stem girth and produced more number of leaves. The delayed flowering in marigold with the application of MH might be due to lesser mitotic activity and preservation of biosynthesis of Gibberellicacid like substances. The present results are in agreement with the findings of Sathappan (2018) and ArtiArha et al., (2019). Similar results were also reported by Girisha et al., (2012), Girwaniet al., (1990) and Khan et al., (2012).

Considering the flower yield per plant, the treatment with NAA@150 ppm recorded for the maximum number of flowers with increased flower weight resulted in maximizing the flower yield (447.2 $\mathrm{g} \mathrm{plant}^{-1}$ ) with an xanthophyll content $\left(18.80 \mathrm{~kg}^{-1}\right.$ of petal meal $(\mathrm{g}))$.

\section{References}

Arti Arha, Paranveer Singh and Verma, L.R. 2019. Regulation of Growth and Flowering by Plant Growth Regulators in African Marigold (Tagetes erecta L.) cv. Lemon Yellow. Int.J.Curr.Microbiol.App.Sci. $\quad$ 8(8): 1704-1708.

Girisha, R., Shiroll, A.M., Kulkarni, B.S., Reddy, B.S. and Anupa, T. 2012. Studies on effect of different plant growth regulators on growth, flowering and quality of daisy (Aster amellus L.) cv. Dwarf Pink.Department of Floriculture and Landscape Architecture, Kittur Rani Channamma College of Horticulture, Arabhavi- 591310

Girwani, A., SrihariBabu, R. and Chandrashekhar, R. 1990. Response of marigold (Tagetes erecta L.) to growth regulators and Zinc. Indian J. Agric. Sci.,60(3): 220-222.

Gowda, N.J.V. and Jayanthi, R. 1991.Effect of cycocel and maleic hydrazide on 
growth and flowering of African marigold (Tagetes erecta L.).Prog. Hort., 23(1-4): 114-118.

Khan, M.I., Muzanil, S., Amir Hasan, M. and Mathew, B. 2012. Efect of different levels of cycocel and malic hydrazide on growth and flowering of African marigold (Tagetes erecta L.) cv. Pusa Narangi Gainda. Asian J. Hort., 7(2): 294-296

Kumar, A., Kumar, J., Mohan, B., Singh, J.P., Rajbeer and Ram, Nathi. 2011. Effect of plant growth regulators on growth, flowering and yield of African marigold (Tagetes erecta L) cv. Pusa Narangi Gainda. Asian J. Hort., 6 (2):418-422

Kumar, M. S., Ponnuswami, V., Jawaharlal, M. and Kumar, R. 2012.Effect of plant growth regulators on growth, yield and exportable quality of cut Roses.J. Life
Sci.,7(4): 733- 738.

Ramdevputra, M.V., Deshmukh, H.N., Butani, A.M., Savaliya, J.J., Pansuriya, A.G. and Kanzaria, D.R. 2009. Effect of different gibberellic acid (GA3) concentrations on growth, flowering and yield of African marigold. Asian J. Hort.,4(1): 82-85.

Sathappan, CT. 2018.Effect of plant growth regulators and pinching on growth and flower yield of African marigold (Tagetes erecta L.)J. Hortl. Sci., 13(1): 42-47.

Tyagi, A. K. and Kumar V. 2006. Effect of gibbrellic acid and vermi compost on vegetative growth and flowering in African marigold (Tagetes erecta Linn.). Journal of Ornamental Horticulture, 9(2): 150-151.

\section{How to cite this article:}

Thirumal Murugan, V., K. Manivannan and Nanthakumar, S. 2020. Studies on the Effect of Plant Growth Regulators on Growth, Flowering and Xanthophyll Content of African Marigold (Tagetes erecta L.). Int.J.Curr.Microbiol.App.Sci. 9(11): 3767-3771. doi: https://doi.org/10.20546/ijcmas.2020.911.452 